\title{
Parvovirus B19 IgM Antibody Measurement
}

National Cancer Institute

\section{Source}

National Cancer Institute. Parvovirus B19 IgM Antibody Measurement. NCI Thesaurus.

Code C96618.

The determination of the amount of parvovirus B19 IgM antibody present in a sample. 